\title{
Tiesību pārsūdzēt lēmumu realizācijas problemātika procesā par noziedzīgi iegūtu mantu
}

\author{
Juris Stukäns \\ Rigas Stradina universitäte, \\ Juridiskā fakultāte, Latvija \\ juris.stukans@tiesas.lv
}

\section{Kopsavilkums}

Rakstā ir aplūkota procesā par noziedzīgi iegūtu mantu iesaistīto personu savu tiesību uz mantu realizācijas problemātika. Darba izstrādes gaitā tika analizēts procesā par noziedzīgi iegūtu mantu iesaistīto personu tiesību realizācijas kriminālprocesuālais regulējums, kā arī Latvijas starptautiskās saistības nodrošināt personu tiesības uz mantu realizāciju noziedzịgi iegūtu līdzekḷ konfiskācijas gadījumā. Pētījuma rezultātā tiek atzìts, ka procesa par noziedzīgi iegūtu mantu kriminālprocesuālais regulējums ir nepilnīgs, neskaidrs un piel̦auj iespēju atšḳirīgi interpretēt tiesību normas, kas iekḷautas Kriminālprocesa likuma 59. nodaḷā - "Process par noziedzīgi iegūtu mantu".

Atslēgvārdi: process par noziedzīgi iegūtu mantu, tiesības pārsūdzēt lēmumu, procesa par noziedzīgi iegūtu mantu dalībnieki.

\section{levads}

2016. gadā Latvijas valdība apṇēmusies pabeigt sarunas par iestāšanos Ekonomiskās sadarbības un attīstības organizācijā (Organisation for Economic Co-operation and Development - OECD). OECD ir 1961. gadā dibināta starpvaldību organizācija, kas apvieno 34 attīstītākās pasaules valstis, tai skaitā arī 21 ES dalībvalsti. OECD definē, ka tās misija ir demokrātijas un tirgus ekonomikas principu ievērošanas veicināšana, kā arī valstu ilgtspējīgas tautsaimniecības attīstības sekmēšana globalizācijas kontekstā [5]. OECD eksperti norāda, ka Latvijai nepieciešams uzrādìt progresu jautājumā par noziedzīgi iegūtu līdzekḷu legalizācijas novēršanu Kukuḷošanas apkarošanas starptautiskajos 
Juris Stukāns. Tiesību pārsūdzēt lēmumu realizācijas problemātika procesā par noziedzīgi iegūtu mantu

biznesa darījumos darba grupai. Iepriekš minētais norāda, ka Latvijā vēl nav izdarīts viss iespējamais, kas nodrošinātu efektīvu noziedzīgi iegūtu līdzekḷu legalizācijas novēršanu un cīnu pret noziedzīgi iegūtu līdzekḷu legalizāciju.

Latvijas Republikas Satversmes 105. pantā noteikts, ka īpašuma tiesības var ierobežot vienīgi saskaṇā ar likumu, savukārt 92. pantā teikts, ka ikviens var aizstāvēt savas tiesības un likumiskās intereses taisnīgā tiesā. Iepriekš minētais likumdevējam uzliek par pienākumu pieņemt tādu normatīvo regulējumu, kas nodrošina ikviena tiesību aizsardzību un likumisku interešu realizāciju īpašuma tiesību aizskaršanas gadījumā. Procesa par noziedzīgi iegūtu mantu mērḳis ir mantisko jautājumu savlaicīga atrisināšana, pieņemot, ka pierādijumu kopums dod pamatu uzskatît, ka mantai, kura izņemta vai kurai uzlikts arests, ir noziedzīga izcelsme vai saistība ar noziedzīgu nodarījumu. Tāpēc ikvienam, kurš uzskata, ka process par noziedzịgi iegūtu mantu aizskar viṇa intereses, jānodrošina iespēja savas tiesības un likumiskās intereses aizstāvēt taisnīgā tiesā.

\section{Darba mērķis}

Izvērtēt tiesību pārsūdzēt rajona (pilsētas) tiesas lēmumu realizācijas iespējas kriminālprocesuālo regulējumu procesā par noziedzīgi iegūtu mantu.

\section{Materiāls un metodes}

Darba izstrādes laikā tika analizēts vēsturiskais un spēkā esošais kriminālprocesuālais regulējums, pielietota tiesību normu vēsturiskā, sistēmiskā, teleologiiskā un gramatiskā interpretācijas metode, kā arī informācijas apkopošanas, sistematizācijas un analīzes izpētes metode.

\section{Diskusija}

Kriminālprocesa likuma 627. panta otrās daḷas 2. punktā noteikts, ka lēmumā uzsākt procesu par noziedzīgi iegūtu mantu procesa virzìtājs norāda, kuras personas ir saistìtas ar konkrēto mantu, tas ir, mantu, kura ir saistìta ar noziedzīgu nodarïumu vai kurai ir noziedzīga izcelsme. Savukārt Kriminālprocesa likuma 628. pants, norādot, kuras personas ir jāinformē par procesa par noziedzīgi iegūtu mantu uzsākšanu, paredz, ka lēmuma kopiju par procesa par noziedzīgi iegūtu mantu uzsākšanu nekavējoties ir jānosūta aizdomās turētajam vai apsūdzētajam un personai, pie kuras manta tika izṇemta vai tai tika uzlikts arests, ja šādas personas attiecīgajā kriminālprocesā ir, vai arī citai personai, kurai ir tiesības uz konkrēto mantu.

No iepriekš minētā izriet, ka ar mantu saistītas personas ir:

- aizdomās turētais vai apsūdzētais;

- persona, pie kuras manta tika izñemta vai tai tika uzlikts arests;

- cita persona, kurai ir tiesības uz konkrēto mantu. 
Juris Stukāns. Tiesību pārsūdzēt lēmumu realizācijas problemātika procesā par noziedzīgi iegūtu mantu

Kriminālprocesa likuma 628. pantā arī noteiktas iepriekš minēto personu tiesības:

- personiski vai ar aizstāvja vai pārstāvja starpniecību piedalīties procesā par noziedzīgi iegūtu mantu;

- mutvārdos vai rakstveidā tiesā izteikt savu attieksmi pret pieṇemto lēmumu;

- iesniegt tiesai pieteikumus.

Tomēr Kriminālprocesa likuma 628. pantā nav paredzēts, ka iepriekš minētās personas var iesniegt sūdzỉbu par tiesas lēmumu.

Salïdzinot procesa par noziedzīgi iegūtu mantu kriminālprocesuālo regulējumu ar kriminālprocesā iesaistīto personu vispārīgiem noteikumiem, ir pamats atzìt, ka gadījumos, kad personai ir tiesības pārsūdzēt rīcību vai nolēmumu, tas tiek norādìts pie konkrētās personas tiesībām. Tāpēc nav skaidrs, kāpēc procesā par noziedzīgi iegūtu mantu personām nav noteikts, ka tās var pārsūdzēt tiesas lēmumu. Arī salīdzinot ar regulējumu par personas, kurai ir tiesības uz aizstāvību, pamattiesībām, Kriminālprocesa likuma $60 .^{2}$ panta pirmās dal̦as 9. punktā noteikts, ka personai, kurai ir tiesības uz aizstāvību, ir tiesības likumā noteiktajos gadījumos, termiṇos un kārtībā pārsūdzēt procesuālos lēmumus. Novērtējot vispārīgo kriminālprocesuālo regulējumu par tiesībām iesniegt sūdzību, tas ir, saskaņā ar Kriminālprocesa likuma 336. panta pirmo dal̦u sūdzību par kriminālprocesu veicošās amatpersonas rīcību vai nolēmumu var iesniegt procesā iesaistītā persona, kā arī persona, kuras tiesības un likumīgās intereses ir aizskartas ar konkrēto rīcību vai nolēmumu, ir pamats atzīt, ka regulējums nav attiecināms uz procesu par noziedzīgi iegūtu mantu. Tiesai, izskatot procesu par noziedzīgi iegūtu mantu, nav pilnvaru konkrētajā kriminālprocesā, jo no konkrētā kriminālprocesa tiek izdalīti materiāli, lai izlemtu kriminālprocesā radušos mantisko jautājumu, kā arì tiesa nav procesa virzītājs, jo kriminālprocesā turpinās izmeklēšana un kriminālprocess paliek iestādē.

Kriminālprocesa likuma 631. panta pirmajā daḷā noteikts, ka tiesas lēmumu 10 dienu laikā var pārsūdzēt apgabaltiesā, sūdzību vai protestu iesniedzot rajona (pilsētas) tiesā. Minētā norma paredz tiesības pārsūdzēt rajona (pilsētas) tiesas lēmumu, bet nenosaka, kuras personas to var izdarìt. Var pieñemt, ka tiesas lēmumu var pārsūdzēt personas, kuras ir saistītas ar mantu, bet tomēr ir pamats jautājumam - kāpēc tas nav noteikts pie personu tiesībām, n̦emot vērā arī citu kriminālprocesā iesaistīto personu tiesību regulējuma principus. Tāpēc ir pamats atzìt, ka regulējums par tiesībām pārsūdzēt rajona (pilsētas) tiesas lēmumu nav precīzs un pięlauj dažādas interpretācijas.

Kriminālprocesa likuma $111 .{ }^{1}$ pants paredz kriminālprocesā iesaistītās personas statusu kā kriminālprocesā aizskartam mantas īpašniekam. Vai šāds kriminālprocesuālais statuss ir personām, kuras iesaistìtas procesā par noziedzīgi iegūtu mantu? No Kriminālprocesa likuma $111 .^{1}$ panta pirmās daḷas izriet, ka kriminālprocesā aizskartais mantas īpašnieks ir îpašnieks vai likumīgais valdītājs, kura tiesības rīkoties ar mantu procesuālo darbību rezultātā ir ierobežotas vai atṇemtas, un ja šai personai nav Kriminālprocesa likumā noteikto tiesību uz aizstāvību. 
Juris Stukāns. Tiesību pārsūdzēt lēmumu realizācijas problemātika procesā par noziedzīgi iegūtu mantu

Tātad procesā par noziedzīgi iegūtu mantu ir tiesības piedalīties personai, kurai ir tiesības uz konkrēto mantu, bet kriminālprocesā var būt iesaistītā persona - īpašnieks vai likumīgais valdītājs, kura tiesības rīkoties ar mantu procesuālo darbību rezultātā ir ierobežotas vai atṇemtas. No iepriekš minētā var secināt, ka procesā par noziedzīgi iegūtu mantu var piedalīties plašāks personu loks, jo tiesības piedalīties netiek ierobežotas ar īpašuma vai valdījuma tiesībām. Tātad Kriminālprocesa likumā ir divi atšḳirīgi regulējumi par personām, kuras var piedalīties procesā par noziedzīgi iegūtu mantu, un personām, kuru tiesības rīkoties ar mantu procesuālo darbību rezultātā ir ierobežotas vai atnemtas.

Interesants ir arī fakts, ka kriminālprocesā aizskartā mantas īpašnieka tiesības atšḳiras no procesā par noziedzīgi iegūtu mantu iesaistīto personu tiesībām.

Kriminālprocesa likuma 111. ${ }^{1}$ panta pirmajā daḷā noteikts, ka mantas īpašniekam vai likumīgajam valdītājam personiski vai ar pārstāvja starpniecību ir šādas tiesības:

1) mutvārdos vai rakstveidā izteikt savu attieksmi pret pieṇemtajiem lēmumiem attiecībā uz mantu;

2) iesniegt pieteikumus vai sūdzības par amatpersonu rīcību vai lēmumiem attiecībā uz mantu;

3) juridiskās palīdzības saṇemšanai uzaicināt advokātu.

Tāpat Kriminālprocesa likuma 111 . $^{1}$ panta otrajā dạ̦ā noteikts, ka mantas īpašniekam ir pienākums pēc procesa virzìtāja pieprasỉjuma rakstveidā paziṇot savu sūtījumu saṇemšanas pasta vai elektronisko adresi un par tās maiṇu, ar ko kriminālprocesā aizskartais mantas īpašnieks apṇemas 24 stundu laikā saṇemt kriminālprocesu veicošās amatpersonas nosūtītos sūtījumus un bez kavēšanās ierasties pēc procesa virzītāja uzaicinājuma vai izpildìt citus minētos kriminālprocesuālos pienākumus.

Personai, kura ir iesaistīta procesā par noziedzịgi iegūtu mantu, Kriminālprocesa likumā pienākumi nav noteikti.

Salīdzinot personas, kura ir iesaistīta procesā par noziedzīgi iegūtu mantu, tiesību regulējumu ar aizskartā mantas īpašnieka tiesību regulējumu, nav saprotams, kāpēc ir atšḳirīgs regulējums un vai tam bija un ir pamatojums. Nemot vērā iepriekš izklāstīto un izvērtējot tiesību normas, ir pamats atzìt, ka ir nepieciešami likuma grozījumi, lai novērstu neprecizitātes un nepilnības.

Kriminālprocesa likumā arī nav noregulēts, pēc kādiem kritērijiem procesa virzītājs procesā par noziedzīgi iegūtu mantu nosaka personu, kurai ir tiesības uz konkrēto mantu. Arī tiesu prakse dod pamatu secināt, ka procesa virzìtājiem, kā arī tiesai nav skaidrības par to, kādām personām ir tiesības piedalīties procesā par noziedzīgi iegūtu mantu. Piemēram, kad tiek arestēts konts bankā, par procesu par noziedzīgi iegūtu mantu un par tiesas sēdi tiek paziņots bankai. Lietā tiek aicināts bankas pārstāvis, bet vai tam ir pamatojums, un vai banka, kas sniedz konkrētai personai pakalpojumu, atbilstoši Kriminālprocesa likumā noteiktajam ir persona, pie kuras manta tika izṇemta vai tai uzlikts arests, vai tomēr tā ir konta îpašnieks. 
Juris Stukāns. Tiesību pārsūdzēt lēmumu realizācijas problemātika procesā par noziedzīgi iegūtu mantu

N̦emot vērā iepriekš izklāstīto, ir pamats secināt, ka būtu nepieciešams sakārtot regulējumu, lai tiesības pārsūdzēt tiesas lēmumu būtu noteiktas skaidri un precīzi, nepieļaujot to apšaubī̌̌anu vai dažādu interpretāciju. Ir jānodrošina, lai likumā konsekventi tiktu lietoti termini. Kriminālprocesa likumā terminu pielietojums nav sakārtots, konsekvents un saskaņots. Vienā normatīvajā aktā jāpielieto vieni un tie paši principi, veidojot tiesību normas, izn,emot gadijumus, kad atšḳirīgai pieejai ir pamatojums un tādējādi arī izskaidrojums. Normatīvā akta teksta neskaidrība kalpo par pamatu atzinumam, ka tiesību realizācija tiek ierobežota.

Regulējums nav precīzs arī gadījumā, kad procesa virzîājs nav personai paziṇojis par savu lēmumu saistībā ar konkrēto mantu, bet persona uzskata, ka tai ir tiesības uz konkrēto mantu, un vēlas iesaistīties procesā, kad materiāli ir jau tiesā.

Uz personas, kurai ir tiesības uz konkrēto mantu, procesuālo garantiju nepietiekamību tika norādìts jau 2010. gada decembrī profesores Ā. Meikališas un profesores K. Stradas-Rozenbergas veiktajā pētijumā "Mantas konfiskācijas tiesiskais regulējums Latvijā un Eiropas Savienībā, tās izpildes mehānisma efektivitātes nodrošināšana". Tajā minēts, ka joprojām aktuāls ir jautājums par iesaistīto personu nepietiekamo procesuālo garantiju sistēmu, jo KPL norādītās šo personu tiesības nevar atzīt par atbilstošām efektīvai tiesību aizsardzībai; noteikti, ka šīm personām neatkarīgi no to procesuālā statusa būtu jābūt tiesībām pašām piedalìties procesā un saṇemt juridisko palīdzību (nevis pašām vai ar kāda starpniecību), kā arī tiesībām izteikt pretargumentus uz pieñēmumu par tām piederošas mantas noziedzīgo izcelsmi, tostarp iesniegt pierādījumus [8].

Latvijas Republikas Saeima 2011. gada 8. jūlijā pieṇēma likumu "Grozījumi Kriminālprocesa likumā” [6], kas stājās spēkā 2011. gada 11. augustā, papildinot Kriminālprocesa likuma 629. pantu ar piekto daḷu, kā arī 629. panta trešajā daḷā svītroja vārdus "un pārbauda iesniegtos pierādījumus" un ceturtajā dạ̦ā vārdus "piedalīties pierādỉjumu pārbaudē". Kriminālprocesa likuma 629. pants regulē tiesas procesu par noziedzīgi iegūtu mantu, nosakot tiesneša rīcību, saṇemot lietu par noziedzīgi iegūtu mantu, un tiesas sēdes gaitu. Kriminālprocesa likuma 629. panta piektā daḷa tika izteikta šādā redakcijā: "Procesa par noziedzīgi iegūtu mantu lietā esošie materiāli ir izmeklēšanas noslēpums, un ar tiem drīkst iepazìties procesa virzìtājs, prokurors un tiesa, kas izskata šo lietu. Šã likuma 628. pantā minētās personas ar lietā esošajiem materiāliem var iepazīties ar procesa virzìtāja aț̦auju un viṇa noteiktajā apjomā."

Iepriekšminētos grozījumus skarbi raksturoja zvērināts advokāts E. Rusanovs, norādot, ka "visbeidzot - trekna svìtra būtiskiem taisnīgas tiesas elementiem tika pārvilkta pāri ar KPL grozījumiem, kas stājās spēkā 2011. gada 11. augustā..” [9].

Jāatzīst, ka ir pamats uzdot jautājumu, vai šāds regulējums, ierobežojot personas tiesības iepazīties ar lietā esošiem materiāliem, nodrošina personai iespēju pilnvērtīgi realizēt savas pārsūdzības tiesības.

Iepriekš minēto priekšlikumu grozìt Kriminālprocesa likuma 629. pantu pēc likumprojekta izskatî̌̌anas otrajā lasijumā kā priekšlikumu iesniedza Tieslietu ministrija. Tieslietu ministrija kā pamatojumu vēstulē norādīja, ka praksē ir atšķirīga izpratne 
Juris Stukāns. Tiesību pārsūdzēt lēmumu realizācijas problemātika procesā par noziedzīgi iegūtu mantu

par to, vai procesa par noziedzīgi iegūtu mantu materiāli ir uzskatāmi par izmeklēšanas noslēpumu. Kā argumentu tā norādīja, ka izmeklēšanas iestādes izvairās uzsākt un sūtìt uz tiesu procesus par noziedzīgi iegūtu mantu, jo ar materiāliem var iepazìties personas, kuras var būt arī aizdomās turētās personas pamata kriminālprocesā, no kura izdalīti materiāli, bet pirmstiesas izmeklēšana tiek turpināta. Tādējādi var tikt apdraudēta kriminālprocesa sekmīga izmeklēšana [7].

Rodas jautājums, vai var atzīt par pamatotu argumentu, ka izmeklěšanas intereses tiek pretstatìtas personas interesēm aizstāvēt savas tiesības uz mantu. Ir jāṇem vērā svarīgs nosacījums, ka procesu par mantas atzīšanu par noziedzīgi iegūtu var uzsākt lielākoties tikai tad, kad objektīvu iemeslu dēl krimināllietas nodošana tiesai drīzumā (saprātīgā laikposmā) nav iespējama. Tādējādi kriminālprocess jau tiek izmeklēts un tuvojas beigām personas tiesību ierobežošanas termiṇi pirmstiesas kriminālprocesā. Turklāt Kriminālprocesa likumā noteikts, ka, izbeidzoties pirmstiesas kriminālprocesa termin,iem, pirmstiesas kriminālprocess pret personu jāpabeidz vai jāatcel visi ierobežojumi. Tāpēc ir pamats atzìt, ka likums paredz termiṇus, kuros procesa virzìtājam būtu jāsavāc un jānostiprina pietiekami daudz pierādījumu, lai izlemtu jautājumu par personas saukšanu pie kriminālatbildības. Nemot vērā iepriekš minēto, ir pamats apšaubīt, vai izmeklēšanas noslēpums var kalpot par pamatojumu turpināt ierobežot personai tiesības zināt pierādījumus, uz kuriem balstās secinājumi par mantas noziedzīgu izcelsmi vai saistību ar noziedzīgu nodarījumu. Ir jāṇem vērā arī otrs nosacỉjums, kad var uzsākt procesu par noziedzịgi iegūtu mantu, proti, pierādījumu kopums dod pamatu uzskatìt, ka mantai, kura izn,emta vai kurai uzlikts arests, ir noziedzīga izcelsme vai saistība ar noziedzīgu nodarījumu. Tātad, uzsākot procesu par noziedzīgi iegūtu mantu, izslēdzot visas sapratīgās šaubas, ir pierādīts, ka manta ir noziedzịgi iegūta. Tāpēc personām vairs nav iespēju ietekmēt jau iegūtos un nostiprinātos pierādījumus. Vērtējot jautājumu par tiesību ierobežošanu iepazīties ar pierādījumiem, ir jāṇem vērā, ka jautājums par mantas atzīšanu par noziedzīgi iegūtu tiek izlemts galīgi un šobrīd likums neparedz šo jautājumu pārskatīt, ņemot vērā kriminālprocesa pabeigšanas veidu un rezultātu (piemēram, kriminālprocess tiek izbeigts, atzīstot, ka nav noticis noziedzīgs nodarījums).

Šobrīd tiek sagatavoti Kriminālprocesa likuma grozījumi, lai nodrošinātu Eiropas Parlamenta un Padomes 2014. gada 3. aprīḷa Direktīvas 2014/42/ES par nozieguma rīku un noziedzīgi iegūtu līdzekḷu iesaldēšanu un konfiskāciju Eiropas Savienībā, kas stājās spēkā 2014. gada 19. maijā un kuras saskaṇā ar Direktīvas 12. pantu ieviešanas termiṇš ir 2016. gada 4. oktobris, prasību ieviešanu Latvijas kriminālprocesuālajā regulējumā [1]. Minētais Kriminālprocesa likuma projekts ir pieejams Ministru kabineta interneta mājas lapā, jo jau 2015. gada 16. jūlijā likumprojekts tika izsludināts Valsts sekretāru sanāksmē. Diemžēl zvērināts advokāts E. Rusanovs 2016. gada 5. janvāra žurnālā "Jurista Vārds" publicētajā rakstā "Procesa par noziedzīgi iegūtu mantu regulējums Kriminālprocesa likumā" norādīja, ka šobrīd Tieslietu ministrijas attiecīgajā darba grupā teju slepeni notiek rosīgs darbs, lai realizētu vērienīgu šì procesa reformu, kas, protams, kārtējo reizi novedis jau pie tik ikdienišşi pierastajiem KPL [Kriminālprocesa likuma] grozijumiem [9]. 
Juris Stukāns. Tiesību pārsūdzēt lēmumu realizācijas problemātika procesā par noziedzīgi iegūtu mantu

Iepazīstoties ar likumprojektu, ir konstatējams, ka netiek mainīts regulējums attiecībā uz procesa par noziedzīgi iegūtu mantu dalībniekiem un viṇu tiesībām, kā arī tiesībām lietas dalībniekiem iepazìties ar procesa par noziedzīgi iegūtu mantu materiāliem.

Latvijai saistošie starptautiskie tiesību akti nosaka pienākumu nodrošināt personai, kuras intereses skar process par noziedzīgi iegūtu mantu, iespēju efektīvi aizstāvēt savas intereses. Eiropas Padomes konvencijas par noziedzīgi iegūtu līdzekḷu legalizācijas un terorisma finansēšanas novēršanu, kā arī šo līdzekḷu meklēšanu, izṇemšanu un konfiskāciju (Varšavas konvencija) 8. pantā noteikts, ka ikviena dalībvalsts pieṇem tādus normatīvos un cita veida aktus, kas var būt nepieciešami, lai nodrošinātu to, ka ieinteresētajām personām, kuras ietekmē 3., 4. un 5. pantā minētie pasākumi un citi attiecīgie šīs sadaḷas noteikumi, ir pieejami efektīvi tiesiskās aizsardzības līdzekḷi, lai aizsargātu šo personu tiesības [2]. Konvencijas 3. pants paredz konfiskācijas pasākumus, 4. pants paredz izmeklēšanas pasākumus un pagaidu pasākumus un 5. pants - ĩpašuma iesaldēšanu, izṇemšanu un konfiskāciju.

Eiropas Padomes konvencijas par noziedzīgi iegūtu līdzekḷu legalizācijas novēršanu, meklēšanu un izņemšanu 5. pantā noteikts, ka ikviena puse veic tādus likumdošanas un cita veida pasākumus, kādi nepieciešami, lai ieinteresētajām personām, uz kurām attiecas 2. un 3. pantā minētie pasākumi, tiek nodrošināta efektīva to tiesību juridiskā aizsardzība [3]. Konvencijas 2. pants paredz konfiskācijas pasākumus un 3. pants - izmeklēšanas pasākumus un pagaidu pasākumus.

Eiropas Savienības Padomes Pamatlēmuma 2005/212/TI (2005. gada 24. februāris) par noziedzīgi iegūtu līdzekḷu, nozieguma rīku un īpašuma konfiskāciju 4. pantā noteikts, ka ikviena dalībvalsts veic pasākumus, kas vajadzīgi, lai ieinteresētajām pusēm, ko skar 2. (konfiskācija) un 3. pantā (paplašinātas konfiskācijas pilnvaras) paredzētie pasākumi, nodrošinātu efektīvus tiesiskās aizsardzības līdzekḷus, lai sargātu to tiesības [4].

Eiropas Parlamenta un Padomes 2014. gada 3. aprịla Direktīvas 2014/42/ES 8. pantā (par aizsargpasākumiem) noteikts, ka dalībvalstis veic nepieciešamos pasākumus, kuru mērḳis ir nodrošināt personām, kuras skar šajā direktīvā noteiktie pasākumi, tiesības uz efektīviem aizsardzības līdzekḷiem un taisnīgu tiesu, lai saglabātu šo personu tiesības. Arī direktīvas preambulas 33. punktā noteikts, ka direktīva būtiski ietekmē personu tiesības - ne tikai aizdomās turēto vai apsūdzēto personu, bet arī tādu trešo personu tiesības, kurām netiek piemērota kriminālvajāšana. Tādēḷ ir jāparedz konkrēti aizsardzības pasākumi un tiesiskās aizsardzības līdzekḷi, lai šìs direktīvas īstenošanas gaitā nodrošinātu šo personu pamattiesību saglabāšanu. Tas ietver to trešo personu tiesības tikt uzklausītām, kas apgalvo, ka ir attiecīgā ìpašuma īpašnieki, vai kas apgalvo, ka tām ir cita veida īpašuma tiesības ("reālas tiesības", "ius in re"), piemēram, lietojuma tiesības [1].

Salīdzinot Latvijas starptautiskās saistības un kriminālprocesuālo regulējumu par personas iespējām efektīvi realizēt savas tiesības, tika konstatēts, ka ir pamats diskusijai par jautājumu, vai Kriminālprocesa likumā ir paredzēti skaidri aizsardzības pasākumi un tiesiskās aizsardzības līdzekḷi, kas nodrošina personu, kuras nav aizdomās turēto vai apsūdzēto personu statusā, pamattiesību aizsardzību. 
Juris Stukāns. Tiesību pārsūdzēt lēmumu realizācijas problemātika procesā par noziedzīgi iegūtu mantu

\section{Secinājumi}

Novērtējot procesa par noziedzịgi iegūtu mantu kriminālprocesuālo regulējumu, jāsecina, ka tiesību pārsūdzēt lēmumu realizācija procesā par noziedzīgi iegūtu mantu ir ierobežota. Procesa par noziedzīgi iegūtu mantu kriminālprocesuālais regulējums ir nepilnīgs, neskaidrs un pię̧auj iespēju atškịīgi interpretēt tiesību normas, kas iekḷautas Kriminālprocesa likuma 59. nodạ̦ā "Process par noziedzīgi iegūtu mantu". Analizējot tiesu lēmumus par mantas atzîšanu par noziedzīgi iegūtu, tika gūts secinājums, ka process par noziedzīgi iegūtu mantu un tiesības pārsūdzēt rajona (pilsētas) tiesas lēmumu nenodrošina personai iespējas pilnvērtīgi aizstāvēt savas intereses.

Vienā normatīvajā aktā jāpielieto vieni un tie paši principi, veidojot tiesību normas, izṇemot gadījumus, kad atšḳirīga pieeja ir pamatota un tādējādi arī izskaidrojama. Normatīvā akta teksta neskaidrība kalpo par pamatu atzinumam, ka tiesību realizācija tiek ierobežota.

\section{Issues Related to the Rights to Appeal in Proceedings Regarding Criminally Acquired Property}

\section{Abstract}

The research is dedicated to the issues of involved persons' rights to property in proceedings regarding criminally acquired property. During development of this research, the author studied the realisation of involved persons' rights in proceedings regarding criminally acquired property. The research examines Latvian international obligations, which ensure persons rights to property in case of confiscation of criminally acquired property. The research reveals that procedural regulation of proceedings regarding criminally acquired property is incomplete, ambiguous and allows possibility to different interpretations of legal provisions contained in the Criminal Procedure Law Chapter 59 - Proceedings regarding criminally acquired property.

Keywords: proceedings regarding criminally acquired property, rights to appeal court decision, participants in proceedings regarding criminally acquired property. 
Juris Stukāns. Tiesību pārsūdzēt lēmumu realizācijas problemātika procesā par noziedzīgi iegūtu mantu

\section{Literatūra}

1. Eiropas Parlamenta un Padomes 2014. gada 3. aprīla Direktīva 2014/42/ES par nozieguma rīku un noziedzīgi iegūtu līdzekḷu iesaldēšanu un konfiskāciju Eiropas Savienībā. Iegūts no: http:// register.consilium.europa.eu/doc/srv?l=LV\&t=PDF\&f=PE+121+2013+REV+2 [sk. 19.03.2016.].

2. Eiropas Padomes konvencija par noziedzīgi iegūtu līdzekḷu legalizācijas un terorisma finansēšanas novēršanu, kā arī šo līdzekḷu meklēšanu, izṇemšanu un konfiskāciju. 16.05.2005. Starptautisks dokuments. Stājas spēkā 01.06.2010. Latvijas Vēstnesis, 205 (4191), 30.12.2009.

3. Eiropas Padomes konvencija par noziedzīgi iegūtu līdzekḷu legalizācijas novēršanu, meklēšanu, izṇemšanu un konfiskāciju. 15.10.1998. Likums. Stājas spēkā 23.10.1998. Latvijas Vēstnesis, 308/312 (1369/1373), 23.10.1998.

4. Eiropas Savienības Padomes 2005. gada 24. februāra Pamatlēmums 2005/212/TI par noziedzīgi iegūtu līdzekḷu, nozieguma rīku un īpašuma konfiskāciju. Iegūts no: http://www.google.lv/url?s $\mathrm{a}=$ t\&rct=j\&q=\&esrc=s\&source=web\&cd=2\&ved=0ahUKEwiYpPPQjebLAhVTKywKHe9zBcg QFggdMAE\&url=http\%3A\%2F\%2Fwww.ejn-crimjust.europa.eu\%2Fejn\%2Flibshowdocument. aspx\%3FId\%3D439\%26Lang\%3DLV\&usg=AFQjCNH3NMjOCcetFaaZKbOuUdd7UTm8Pg [sk.19.03.2016.].

5. Ekonomiskās sadarbības un attīstības organizācija (OECD). Iegūts no: http://www.mfa.gov. lv/arpolitika/ekonomiskas-attiecibas/starptautiskas-ekonomiskas-organizacijas/ekonomiskassadarbibas-un-attistibas-organizacija-esao [sk. 18.03.2016.].

6. Grozījumi Kriminālprocesa likumā. 08.07.2011. Likums. Stājas spēkā 11.08.2011. Latvijas Vēstnesis, 117 (4515), 28.07.2011.

7. Latvijas Republikas Tieslietu ministrija. Saeimas Juridiskās komisijas priekšsēdētājai I. Čepānes kundzei [vēstule]. Iegūts no: http://titania.saeima.lv/LIVS10/SaeimaLIVS10.nsf/0/73d4418a92 c0cc78c22578b6003cb839/\$FILE/2_1982.pdf [sk.19.03.2016.].

8. Meikališa, Ā., Strada-Rozenberga, K. Pētījums "Mantas konfiskācijas tiesiskais regulējums Latvijā un Eiropas Savienībā, tās izpildes mehānisma efektivitātes nodrošināšana”. Iegūts no: www.tm.gov.lv/lv/ministrija/imateriali/MantKonf.pdf [sk. 19.03.2016.].

9. Rusanovs, E. Procesa par noziedzīgi iegūtu mantu regulējums Kriminālprocesa likumā. Jurista Vārds, 2016; 1 (904): 24.-31. lpp. 